\title{
Effect of calcium and mineral waters on oleic-acid uptake by isolated hamster enterocytes
}

\author{
J Goré ${ }^{1}, \mathrm{C}$ Hoinard ${ }^{1}$, JM Antoine ${ }^{2}, \mathrm{C} \mathrm{Couet}^{3}$
}

\author{
1 JE 313 (DRED), Laboratoire de Physiologie et Biophysique Cellulaires, Faculté de Pharmacie, \\ 31, avenue Monge, 37200 Tours; \\ 2 Direction Scientifique Nutrition-Toxicologie, Groupe BSN, 75381 Paris Cedex 08; \\ 3 JE 313 (DRED), Laboratoire de Nutrition, Faculté de Médecine, 2 bis, boulevard Tonnellé, \\ 37032 Tours, France
}

(Received 15 February 1994; accepted 11 July 1994)

\begin{abstract}
Summary - The effect of calcium upon the uptake of oleic acid solubilized with $10 \mathrm{mM}$ taurocholate was investigated using an in vitro model of isolated enterocytes. The addition of $\mathrm{Ca}^{2+}$ to the incubation medium (Hanks' medium) led to a decrease in oleic-acid uptake. This uptake inhibition was dependent on both the amount of $\mathrm{Ca}^{2+}$ and the fatty-acid concentration, since the inhibitory effect was significant for $10 \mu \mathrm{M}$ but not $100 \mu \mathrm{M}$ oleic acid. The determination of the monomeric activity of oleic acid indicated that the decrease in fatty-acid uptake was not linked to the formation of insoluble calcium soaps. The replacement of Hank's medium by several mineral waters containing between 0.3 and $11.7 \mathrm{mM} \mathrm{Ca}^{2+}$ significantly reduced the uptake of both 10 and $100 \mu \mathrm{M}$ oleic-acid. The ionic composition of these waters was correlated with the decrease of initial rate of oleic acid uptake, but $\mathrm{Ca}^{2+}$ and other ions could interfere by synergetic effects with the fatty-acid-absorption mechanism. It is concluded that the ioninduced inhibition of oleic-acid uptake is not due to the formation of insoluble soaps but rather to a direct effect on the fatty-acid transport in membranes. Whether the fatty-acid binding protein in the plasma membrane is involved in the effect of $\mathrm{Ca}^{2+}$ on fatty-acid transport remains to be established.
\end{abstract}

$\mathrm{Ca}^{2+} /$ mineral water / oleic acid / intestinal absorption / isolated enterocytes / hamster

Résumé - Influence du calcium et d'eaux minérales sur le captage de l'acide oléique par les entérocytes isolés du hamster. L'influence du calcium sur le captage de l'acide oléique solubilisé par 10 $\mathrm{mM}$ de taurocholate est étudiée sur un modèle in vitro d'entérocytes isolés. L'addition de $\mathrm{Ca}^{2+} \mathrm{au}$ milieu d'incubation (milieu de Hanks) induit une diminution du captage de l'acide oléique. Cette inhibition du captage dépend de la concentration en calcium ajouté, et de la concentration en acide gras puisque l'effet est significatif pour $10 \mu \mathrm{M}$ mais pas pour $100 \mu \mathrm{M}$ d'acide oléique. L'évaluation de l'activité monomérique de l'acide oléique suggère que linhibition du captage n'est pas liée à la formation de savons calciques insolubles. Le remplacement du milieu de Hanks par différentes eaux minérales apportant entre 0,3 et $11,7 \mathrm{mM}$ de $\mathrm{Ca}^{2+}$ conduit à une diminution très significative du captage de l'acide oléique 10 et $100 \mu \mathrm{M}$. Les corrélations établies entre la composition ionique de ces eaux et la vitesse initiale de captage de l'acide gras indiquent que, outre $\mathrm{Ca}^{2+}$, d'autres ions par un effet de synergie doivent inter- 
férer avec le mécanisme d'absorption de cet acide gras. En conclusion, l'inhibition du captage de l'acide oléique produite par les ions présents dans le milieu d'incubation n'est pas due à la formation de savons insolubles mais plutôt à un effet direct sur le transport entérocytaire, vraisemblablement lié à la protéine membranaire chargée du transport des acides gras à longue chaîne.

\section{$\mathrm{Ca}^{2+}$ / eaux minérales / acide oléique / absorption intestinale / entérocytes isolés / hamster}

\section{INTRODUCTION}

Several epidemiological studies indicate that the incidence of colon cancer is positively correlated with the dietary fat intake (Willett, 1989; Willett et al, 1990; Weisburger, 1991) and negatively correlated with the intake of calcium (Appleton et al, 1987; Sorenson et al, 1988). One mechanism by which calcium might reduce the effect of fat may be the formation of insoluble salts with bile acids and free fatty acids (Wargovich et al, 1983, 1984; Newmark et al, 1984; Lipkin and Newmark, 1985). It is generally admitted that soluble calcium $\left(\mathrm{Ca}^{2+}\right)$ in the intestinal lumen precipitates fatty acids leading to an increase in faecal fatty-acid excretion and a decrease in intestinal fatty acid absorption (Mattson et al, 1979; Appleton et al, 1992; Govers and Van der Meer, 1993). However, some studies have shown a significant stimulation of the rate of fattyacid absorption by calcium ions (Strauss, 1977; Bernard et al, 1989; Saunders and Sillery, 1989). These conflicting results could be explained by the use of different experimental conditions which led to the proposal various mechanisms for intestinal fatty-acid uptake (simple diffusion, facilitated diffusion, and active transport). There are increasingly more arguments showing that the cell uptake of long-chain fatty acids occurs according to a carrier-mediated process. These results were obtained with in vitro studies using everted intestinal sacs or isolated perfused intestines (Chow and Hollander, 1978, 1979; Hollander et al, 1984; Molina et al, 1990). Studies using isolated intestinal cells indicate that oleic-acid uptake
(Stremmel, 1988) and $\alpha$-linolenic acid uptake (Goré and Hoinard, 1993) occur via a facilitated membrane translocation process, utilizing a fatty-acid binding protein in the membrane (Stremmel et al, 1985). The activity of this membrane transport protein could be modulated by extracellular medium, particularly its mineral composition.

We report here on the effect of calcium and other ions on the uptake of micellar solutions of oleic acid/taurocholate by isolated hamster intestinal cells. The effect of calcium on oleic-acid uptake was analysed: i) by adding $\mathrm{CaCl}_{2}$ to the physiological incubation solution (Hanks' medium); or ii) by replacing the incubation medium by mineral waters containing different levels of ions, particularly calcium $(0.3-11.7 \mathrm{mM})$.

\section{MATERIALS AND METHODS}

\section{Animals}

Fifteen adult male Syrian hamsters weighing 120-140 g (Elevage Dépré, Saint-Doulchard, France) were used. They were fed with a standard diet (ref 105, UAR, Villemoisson, France). Before experiments they were fasted overnight, but had free access to tap water.

\section{Chemicals}

Unless otherwise stated all chemicals were purchased from Sigma Chimie (Saint-QuentinFallavier, France). [1-14 C]Oleic acid (2.1 $\mathrm{GBq} / \mathrm{mmol}$ ) was purchased from New England Nuclear (Du Pont de Nemours, Paris, France). 
The scintillation liquid Optiphase 'Hisafe' II was obtained from LKB (Pharmacia, Saint-Quentinen-Yvelines, France). Solutions of labeled oleic acid were prepared by isotopic dilution.

\section{Experimental procedure}

\section{Preparation of intestinal cells}

Intestinal cells were isolated as previously described (Goré and Hoinard, 1987, 1989). Briefly, the hamsters were killed by diethyl ether overexposure (Scientist authorisation No 2897, ministère de l'Agriculture et de la Forêt, France) and the entire small intestine was removed, rinsed with oxygenated buffer solution $\left(95 \% \mathrm{O}_{2}, 5 \%\right.$ $\mathrm{CO}_{2}$ ) containing $27 \mathrm{mM}$ sodium citrate, and incubated for $10 \mathrm{~min}$ in the same buffer at $37^{\circ} \mathrm{C}$. It was then emptied, filled with oxygenated buffer solution containing $1.5 \mathrm{mM}$ ethylenediaminetetraacetic acid, incubated for $3 \mathrm{~min}$ at $37^{\circ} \mathrm{C}$ and then gently finger palpated for $2 \mathrm{~min}$. This treatment was repeated twice. The buffer containing intestinal cells was recovered in Hanks' solution. After centrifugation $(765 \mathrm{~g}$ ) the isolated cells were resuspended in Hanks' medium containing collagenase type IA $\left(37^{\circ} \mathrm{C}, 15 \mathrm{~min}\right.$ with stirring). The intestinal cells were then washed twice and resuspended in Hanks' medium (cellular stock solution containing about $5 \mathrm{mg}$ protein $/ \mathrm{ml}$ ). Light microscopy of the suspension showed that about $90 \%$ of the cells displayed the typical features of villus-tip cells. Viability was assessed by trypan blue exclusion capacity and lactate dehydrogenase (EC 1.1.1.27) release assay, using lactate dehydrogenase optimized kit No DG1340-K, Sigma diagnostics (Sigma Chimie, Saint-QuentinFallavier, France). Protein concentration was assayed with the method of Lowry et al (1951).

\section{Preparation of solutions}

\section{Mineral water}

Four commercial mineral waters (Volvic, Evian, Vittel and Contrex) containing between 0.3 and $11.7 \mathrm{mM} \mathrm{Ca}^{2+}$ and commonly used in French diets, were chosen for this study. Table I shows the mineral content of these waters and indicates a very low osmolarity. Because intestinal cells were resuspended in these waters in the experimental protocol, it was necessary to adjust the medium osmolarity and $\mathrm{pH}$ at physiological values (ie $290 \mathrm{mOsm} / \mathrm{kg} \mathrm{H} \mathrm{H}_{2} \mathrm{O}$ and $\mathrm{pH} 7.3$ ). This was done by adding mannitol $(240-265 \mathrm{mM})$ and Hepes $(10 \mathrm{mM})$ to these waters.

\section{Working cellular suspensions}

Six millilitres of cellular stock solution were centrifuged (765 $\mathrm{g}, 2 \mathrm{~min}$ ) and the pellet was resuspended in $6 \mathrm{ml}$ of control medium (Hanks' medium) or $6 \mathrm{ml}$ of mineral water (working cellular suspension containing about $5 \mathrm{mg}$ protein/ml).

Table I. Composition* of mineral waters and Hanks' medium.

lons (mg/l) Water 1 (Volvic) Water 2 (Evian) Water 3 (Vittel) Water 4 (Contrex) Hanks' medium

\begin{tabular}{|c|c|c|c|c|c|}
\hline $\mathrm{Ca}^{2+}$ & $9.9(0.26 \mathrm{mM})$ & $78(1.95 \mathrm{mM})$ & $202(5.05 \mathrm{mM})$ & $467(11.67 \mathrm{mM})$ & $50(1.26 \mathrm{mM})$ \\
\hline $\mathrm{Mg}^{2+}$ & 6.1 & 24 & 36 & 84 & 19.7 \\
\hline $\mathrm{Na}^{+}$ & 9.4 & 5.0 & 3.0 & 7.0 & 3164 \\
\hline $\mathrm{K}^{+}$ & 5.7 & 1.0 & - & 3.0 & 227 \\
\hline $\mathrm{Cl}^{-}$ & 8.4 & 4.5 & - & 7.0 & 5139 \\
\hline $\mathrm{SO}_{4}^{2-}$ & 6.9 & 10 & 306 & 1192 & 79 \\
\hline $\mathrm{HCO}_{3}^{-}$ & 65.3 & 357 & 402 & 377 & 0 \\
\hline Total ion & 109 & 309 & 750 & 1850 & 9790 \\
\hline $\mathrm{pH}$ & 7.0 & 7.2 & 7.4 & 7.2 & 7.3 \\
\hline Osmolarity & 1 & 6 & 11 & 24 & 276 \\
\hline
\end{tabular}

\footnotetext{
* Compositions determined by the manufacturer.
} 


\section{Fatty-acid solutions}

Five millilitres of fatty-acid solution were prepared by isotopic dilution of $\left[1-{ }^{14} \mathrm{C}\right]$ oleic acid $(20 \mu \mathrm{M}$ or $200 \mu \mathrm{M})$ in Hanks' medium, Hanks' medium plus $\mathrm{CaCl}_{2}(6 \mathrm{mM}$ or $20 \mathrm{mM})$, or mineral water; each medium contained $20 \mathrm{mM}$ sodium taurocholate. Solubilization was obtained by sonication for 5 min in a Ney 300 water-bath sonicator (Bioblock Scientific, Illkirch, France).

\section{Determination of oleic-acid uptake}

Uptake of [1-14C]oleic acid was measured by rapid vacuum filtration assay (Stremmel, 1988). One millititre of the working cellular suspension was incubated for $1 \mathrm{~min}$ in a $37^{\circ} \mathrm{C}$ water bath with stirring and uptake was started by the addition of $1 \mathrm{ml}$ of fatty-acid solution (medium plus sodium taurocholate) containing $\left[1-{ }^{-14} \mathrm{C}\right]$ oleic acid at $37^{\circ} \mathrm{C}$. At various time intervals over the initial 20-s incubation period, $200 \mu \mathrm{l}$ sample aliquots (about $0.5 \mathrm{mg}$ protein) were pipetted into $3 \mathrm{ml}$ of $5 \mathrm{mg}$ albumin/ml in Hanks' medium $\left(4^{\circ} \mathrm{C}\right)$ to stop cellular influx and to remove bound fatty acids. The stop solution with cells was pipetted onto the center of Whatman GF/C glass microfibre filter (Poly Labo, Strasbourg, France), and filtered under $8 \times 10^{4} \mathrm{~Pa}$ vacuum pressure using a filtration apparatus (Hoefer model FH225V, Bioblock, Illkirch, France). Celis were washed with $5 \mathrm{ml}$ of $5 \mathrm{mg}$ albumin $/ \mathrm{ml}$ solution $\left(4^{\circ} \mathrm{C}\right)$ and thereafter with $20 \mathrm{ml}$ of Hanks' medium $\left(4^{\circ} \mathrm{C}\right)$. Filters were placed in scintillation vials, and $4 \mathrm{ml}$ of scintillation liquid was added. Radioactivity was determined in a LKB-1215 Rackbeta liquid scintillation counter (Pharmacia, Saint-Quentin-en-Yvelines, France). Nonspecific radioactivity binding to filters and cells was measured in each experiment by adding $5 \mathrm{mg}$ albumin $/ \mathrm{ml}$ in Hanks' medium $\left(4^{\circ} \mathrm{C}\right)$ before the addition of corresponding aliquots of cells and $[1-14 \mathrm{C}]$ oleic-acid working solutions. This background was $<5 \%$ of the total radioactivity measured. The value of each sample was the net radioactivity after subtraction of this blank.

\section{Determination of oleic-acid monomer activity}

The technique used to determine monomer activity is based upon the partitioning of fatty acids between aqueous solution and a solid organic phase, a polyethylene disc. With this system,
Sallee (1974) demonstrated that monomer activities of solutions of long-chain fatty acids dissolved in bile acid were linearly dependent on the total fatty-acid concentration in the incubation medium. Polyethylene discs, $1.2 \mathrm{~cm}$ in diameter, were punched from $0.16 \mathrm{~mm}$ thick polyethylene film manufactured by Roth Sochiel (Lauterbourg, France). To remove any oil and debris, the discs were washed in methanol and distilled water and were dried before used. After equilibration of 2 discs in $3 \mathrm{ml}$ fatty-acid test solutions for $24 \mathrm{~h}$ (shaking water bath, $37^{\circ} \mathrm{C}$ ) the discs were removed, rinsed in Hanks' medium and the radioactivity associated with the discs was determined.

\section{Statistical analysis}

Results are expressed as means \pm SE. Initial rates of uptake $\left(V_{i}\right)$ were calculated by the method of least squares, which allows an estimation of simple linear regression parameters and their standard deviations. Comparisons of ordinates at origin with zero value were evaluated by Student's $t$-test. Curves characterizing the intracellular uptake of oleic acid were calculated with Microsoft Excel solver (Les Ulis, France). Comparisons between group means were evaluated by the unpaired $t$-test. Statistical significance of differences among more than 2 groups were determined by analysis of variance (PCSM programs, Deltasoft, Grenoble, France).

\section{RESULTS}

The aim of this work was to study the influence of calcium on the intestinal absorption of oleic acid. The dispersion of fatty acids in the incubation medium is one of the indispensable conditions for studying their uptake by intestinal cells. Some authors have used bovine serum albumin to complex fatty acids (Stremmel, 1988; Potter et al, 1989; Trotter and Storch, 1991). During the intestinal absorption process, fatty acids were physiologically solubilized by bile salts present in the lumen. Thus, we chose to use sodium taurocholate (final concentration $10 \mathrm{mM}$ ) as a dispersing agent in this study. 


\section{Cell viability}

Because bile salts have been shown to affect the viability or permeability of intestinal cells (Westergaard and Dietschy, 1976; Buset et al, 1990), we tested the effect of $10 \mathrm{mM}$ taurocholate on the cells. In the Hanks' medium without taurocholate, initial cell viability was about $85 \%$. The addition of $10 \mathrm{mM}$ taurocholate led to a decrease of cellular viability of 1.5 and $2 \%$ per min when assessed by trypan blue exclusion and lactate dehydrogenase release, respectively. Because incubation time with taurocholate was $<1 \mathrm{~min}$ (see Materials and methods) cellular viability loss resulting from the presence of taurocholate was not significant. In addition, prior work in our laboratory has shown that permeability was not significantly modified by taurocholate (Goré and Hoinard, 1993).

\section{Kinetics of intracellular oleic-acid uptake}

Figure 1 shows an example of absorption kinetics for $100 \mu \mathrm{M}$ oleic acid solubilized in $10 \mathrm{mM}$ taurocholate. During the first $20 \mathrm{~s}$ of incubation the rate of uptake was maximal

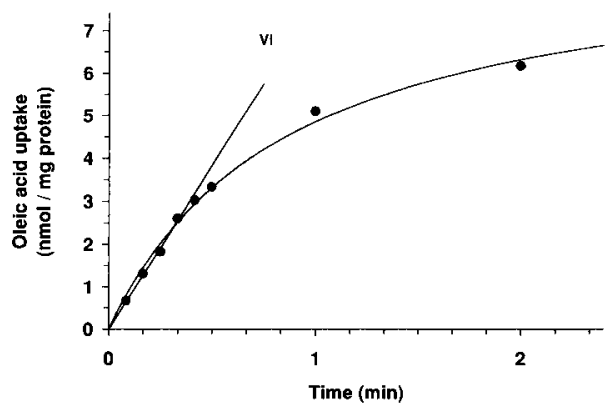

Fig 1. An example of the time course of oleic-acid uptake by isolated enterocytes at $37^{\circ} \mathrm{C} \cdot\left[1-{ }^{14} \mathrm{C}\right]$ Oleic acid solubilized in taurocholate (final concentrations $100 \mu \mathrm{M}$ and $10 \mathrm{mM}$, respectively) was added to cellular suspension (final protein concentration $2.5 \mathrm{mg} / \mathrm{ml})$. Initial rate of uptake $\left(V_{i}\right)$ was calculated by linear regression fit from uptake measured over the initial 20-s incubation period. and linear. The initial rate of uptake $\left(V_{i}\right)$ was determined by linear regression fit from uptake measured over the initial 20-s incubation period. Statistical tests indicated no significant difference between ordinate at origin and the zero value.

\section{Effect of the incubation medium on cellular uptake of oleic acid}

Table II shows that when the oleic-acid monomer was solubilized in $10 \mathrm{mM}$ sodium taurocholate, its activity was not significantly modified by the addition of calcium to the incubation medium. Similarly, replacement of incubation medium by the mineral waters with higher ionic concentrations (particularly in calcium) did not lead to any changes in monomeric activity. Table III, however, indicates that the addition of $\mathrm{CaCl}_{2}$ to the control incubation medium (Hanks' medium) induced a significant decrease in $10 \mu \mathrm{M}$ oleic-acid cellular uptake. The effect of $\mathrm{CaCl}_{2}$ was dependent on the amount of $\mathrm{Ca}^{2+}$ added to the medium (inhibition of 19 and $32 \%$ for 3 and $10 \mathrm{mM} \mathrm{CaCl}_{2}$, respectively). Although a reduction in fatty-acid uptake was noted, the intestinal absorption of $100 \mu \mathrm{M}$ oleic acid was not significantly modified by $\mathrm{CaCl}_{2}$. On the other hand, replacement of Hanks' medium by mineral waters drastically decreased the cellular uptake of both 10 and $100 \mu \mathrm{M}$ oleic acid (mean inhibition $60 \pm 16 \%$ ). It can be noted that the decrease of oleic-acid uptake induced by mineral waters was even greater than those obtained with $10 \mathrm{mM} \mathrm{CaCl}_{2}$. Statistical analysis revealed that the inhibition of fatty-acid uptake was different from one water to the others. The examination of the mineral content of these waters (see table I) leads to 2 remarks: i) in comparison to the Hanks' medium, all the waters used in this study were $\mathrm{Na}^{+-}, \mathrm{K}^{+}$- and $\mathrm{Cl}^{-}$-depleted; and ii) the amounts of $\mathrm{Ca}^{2+}, \mathrm{Mg}^{2+}, \mathrm{SO}_{4}{ }^{2-}$ and $\mathrm{HCO}_{3}$ - increased from water 1 to water 4 (ie Volvic < Evian < Vittel < Contrex). Table IV 
Table II. Effect of $\mathrm{Ca}^{2+}$ and water 4 (Contrex) on oleic-acid content of polyethylene discs.

Medium

Oleic acid $(10 \mu \mathrm{M}) \quad$ Oleic acid $(100 \mu \mathrm{M})$

$\begin{array}{llll}\text { Hanks' (control) } & 8 & 448 \pm 9 & 6174 \pm 153 \\ \text { Hanks' }^{\prime} \mathrm{CaCl}_{2} 3 \mathrm{mM} & 7 & 423 \pm 11 & 5748 \pm 152 \\ \text { Hanks' }+\mathrm{CaCl}_{2} 10 \mathrm{mM} & 7 & 542 \pm 36 & 4616 \pm 355 \\ \text { Water } 4 \text { (Contrex) } & 8 & 549 \pm 15 & 5288 \pm 670\end{array}$

Values are means \pm SE of $n$ experiments. Incubation medium contained 10 or $100 \mu \mathrm{M}$ oleic acid solubilized in 10 $\mathrm{mM}$ taurocholate. There is no statistical difference $(P>0.05)$ between the means for oleic acid $10 \mu \mathrm{M}$, and for oleic acid $100 \mu \mathrm{M}$ (analysis of variance).

Table III. Effect of $\mathrm{Ca}^{2+}$ and mineral water on oleic-acid uptake $(10$ and $100 \mu \mathrm{M})$ by isolated hamster enterocytes.

Medium

n

Hanks' (control)

Hanks' $+\mathrm{CaCl}_{2} 3 \mathrm{mM}$

Hanks' $+\mathrm{CaCl}_{2} 10 \mathrm{mM}$

Water 1 (Volvic)

Water 2 (Evian)

Water 3 (Vittel)

Water 4 (Contrex)
40

8

8

8

8

8

8
Initial rate of uptake (pmol/mg protein/min)

Oleic acid $(10 \mu \mathrm{M}) \quad$ Oleic acid $(100 \mu \mathrm{M})$

$\begin{array}{ll}1853 \pm 59 & 7385 \pm 401 \\ 1506 \pm 53^{a} & 6927 \pm 229 \\ 1260 \pm 48^{a b} & 6469 \pm 306 \\ & \\ 978 \pm 35^{a} & 4815 \pm 132^{a} \\ 700 \pm 23^{a} & 3840 \pm 162^{a} \\ 591 \pm 16^{a} & 2607 \pm 99^{a} \\ 230 \pm 8^{a} & 2474 \pm 142^{a c}\end{array}$

Values are means $\pm S E$ of $n$ experiments. Incubation medium contained 10 or $100 \mu \mathrm{M}$ oleic acid solubilized in $10 \mathrm{mM}$ taurocholate. Comparisons to control (Hanks' medium) a $P<0.001$. Comparison between $\mathrm{CaCl}_{2} 3 \mathrm{mM}$ and $10 \mathrm{mM}$, b $P<0.01$. Comparison between water 3 and water $4, c P>0.05$, no statistical difference.

indicates that total ion content of the waters was statistically inversely correlated to the uptake of oleic acid $(r=-0.948, P<0.001$ and $r=-0.811, P<0.001$ for oleic acid uptake 10 and $100 \mu \mathrm{M}$, respectively). The ions $\mathrm{Ca}^{2+}, \mathrm{Mg}^{2+}$ and $\mathrm{SO}_{4}{ }^{2-}$ especially seem to play an inhibitory role in oleic acid cellular uptake $(-0.969<r<-0.824 ; P<$ $0.001)$. In order to clarify this point, some complementary experiments were con- ducted (table V). First, the influence of $\mathrm{Cl}^{-}$ or $\mathrm{SO}_{4}{ }^{2-}$ was apparently negligible since no important change in oleic-acid uptake was demonstrated when $\mathrm{CaSO}_{4}$ was substituted for $\mathrm{CaCl}_{2}$, or when $\mathrm{NaCl}(140 \mathrm{mM})$ was added to $\mathrm{Na}^{+}$-depleted water (water 4). This addition of $\mathrm{Na}^{+}$led to a significant increase of oleic-acid uptake, which was insufficient for control level recovery. Second, the addition of $10 \mathrm{mM}$ EGTA, which 
Table IV. Correlation table between ionic composition of mineral waters and initial rate of uptake $\left(V_{i}\right)$ of 10 and $100 \mu \mathrm{M}$ oleic acid.

\begin{tabular}{|c|c|c|c|c|c|c|c|c|}
\hline & Totalion & $\mathrm{Ca}^{2+}$ & $M g^{2+}$ & $\mathrm{SO}_{4}{ }^{2-}$ & $\mathrm{HCO}_{3}^{-}$ & $K^{+}$ & $\mathrm{Na}^{+}$ & $\mathrm{Cr}^{-}$ \\
\hline- & - $\cdots$ & $\cdots$ & $\cdots$ & - & $\cdots$ & & & $\ldots$ \\
\hline $\begin{array}{l}\text { Total ion } \\
\mathrm{Ca}^{2+}\end{array}$ & $\begin{array}{l}1 \\
0.998\end{array}$ & 1 & & & & & & \\
\hline $\begin{array}{l}\mathrm{Ca}^{2+} \\
\mathrm{Mg}^{2+}\end{array}$ & $\begin{array}{l}0.998 \\
0.993\end{array}$ & $\begin{array}{l}1 \\
0.994\end{array}$ & 1 & & & & & \\
\hline $\mathrm{SO}_{4}{ }^{2-}$ & 0.991 & 0.982 & 0.975 & 1 & & & & \\
\hline $\mathrm{HCO}_{3}^{-}$ & 0.570 & 0.613 & 0.636 & 0.458 & 1 & & & \\
\hline $\mathrm{K}^{+}$ & -0.19 & -0.222 & -0.302 & -0.088 & -0.88 & 1 & & \\
\hline $\mathrm{Na}^{+}$ & -0.1 & -0.156 & -0.15 & 0.03 & -0.84 & 0.999 & 1 & \\
\hline $\mathrm{Cl}^{-}$ & 0.056 & 0.023 & -0.06 & 0.158 & -0.737 & 0.970 & 0.977 & 1 \\
\hline $\begin{array}{l}V_{i}(10 \mu \mathrm{M}) \\
V_{i}(100 \mu \mathrm{M})\end{array}$ & $\begin{array}{l}-0.948 \\
-0.811\end{array}$ & $\begin{array}{l}-0.958 \\
-0.842\end{array}$ & $\begin{array}{l}-0.969 \\
-0.824\end{array}$ & $\begin{array}{l}-0.906 \\
-0.736\end{array}$ & $\begin{array}{l}-0.757 \\
-0.866\end{array}$ & $\begin{array}{l}0.439 \\
0.483\end{array}$ & $\begin{array}{l}0.323 \\
0.631\end{array}$ & $\begin{array}{l}0.210 \\
0.258\end{array}$ \\
\hline
\end{tabular}

The correlation coefficients in bold type are highly significant $(P<0.001)$.

Table V. Effect of the incubation medium on $10 \mu \mathrm{M}$ oleic-acid uptake by isolated hamster enterocytes.

Medium

Hanks' (control)

Hanks' $+\mathrm{CaCl}_{2} 10 \mathrm{mM}$

Hanks' $+\mathrm{CaSO}_{4} 10 \mathrm{mM}$

Water 4 (Contrex)

Water 4 (Contrex) + 10 mM EGTA

Water 4 (Contrex) + $140 \mathrm{mM} \mathrm{NaCl}$

$\begin{array}{rc}24 & 1693 \pm 37 \\ 8 & 1466 \pm 56^{\mathrm{a}} \\ 8 & 1532 \pm 39^{\mathrm{ac}} \\ 16 & 625 \pm 23^{\mathrm{b}} \\ 8 & 763 \pm 28^{\mathrm{bd}} \\ 8 & 823 \pm 16^{\mathrm{bd}}\end{array}$

Values are means \pm SE of $n$ experiments. Incubation medium contained $10 \mu \mathrm{M}$ oleic acid solubilized in $10 \mathrm{mM}$ taurocholate. Comparisons to control (Hanks' medium), a $P<0.01$, b $P<0.001$. Comparisons between $\mathrm{CaCl}_{2}$ and $\mathrm{CaSO}_{4}$, c $P>0.05$, no statistical difference. Comparison between water 4 and water $4+\mathrm{EGTA}$, or water $4+\mathrm{NaCl},{ }^{d} P<0.001$.

induced a decrease of $\mathrm{Ca}^{2+}$ content of water 4 (Contrex) from 11.7 to $1.3 \mathrm{mM}$, could not restore the oleic-acid uptake measured in the control.

\section{DISCUSSION}

The results obtained in the first part of this study show that when calcium was added to intestinal cell incubation medium, the uptake of oleic acid (18:1n-9) was reduced. The extent of this effect increased as the calcium concentration in the medium was raised. For the same calcium concentration, the decrease of uptake was greater at low concentration of fatty acids (table III). A $\mathrm{Ca}^{2+} /$ fatty acid molar ratio $>100$ is required before decreased oleic-acid uptake was noted. Similar results were obtained with 
linolenic acid (18:3n-3), a long-chain polyunsaturated fatty acid (data not shown). This agrees with the reduction in long-chain fattyacid uptake brought about by calcium as reported by several authors (Mattson et al, 1979; Appleton et al, 1992; Govers et al, 1993). In the present study, the decrease in oleic-acid uptake induced by calcium was not directly related to the formation of insoluble calcium soaps. As indicated by the determination of monomeric activities, the fatty-acid monomer, which is the only form easily absorbed by intestinal cells (Westergaard and Dietschy, 1976), was not modified by the addition of calcium (table II). This lack of formation of insoluble products could depend on our experimental conditions (oleic acid dissolved in $10 \mathrm{mM}$ taurocholate, $\mathrm{pH}$ 7.30). Jandacek (1991) has shown that the solubility of calcium oleate is $40-50 \mathrm{mg} / \mathrm{l}$ (about $1200 \mu \mathrm{M}$ ), ie much higher than the concentrations used in the present work. In addition, calcium has relatively little effect on the absorption of unsaturated fatty acids (Mattson et al, 1979; Guéguen, 1992) and oleic acid itself would cause the solubilization of calcium-oleate salts (Jandacek, 1991). Finally, the presence of taurocholate could modify the $\mathrm{Ca}^{2+}$-fatty-acid interaction (Van der Meer et al, 1990; Gu et al, 1992; Govers and Van der Meer, 1993). Calcium thus appears to interfere directly or indirectly with the fatty-acid-uptake mechanisms of intestinal cells, rather than through a reduction in the concentration of free fatty acid that can be absorbed. Whether $\mathrm{Ca}^{2+}$ reduces oleate uptake through modifications in the membrane fluidity (Jacobson and Papahadjopoulos, 1975; Baciulis et al, 1992) and/or in the activity of the membrane fatty-acid binding protein which transports long-chain fatty acids into intestinal cells (Stremmel, 1988; Goré and Hoinard, 1993) cannot be assessed from the present study.

The results of the second part of this study, involving the effect of mineral water on oleic-acid uptake, are not so straightforward to interpret. Overall, replacing the incuba- tion medium used as control (Hanks' medium) by mineral water led to an approximately $60 \%$ reduction of fatty-acid uptake. This inhibition of transport was noted with both 10 and $100 \mu \mathrm{M}$ oleic acid. Intestinal cell uptake of long-chain fatty acids requires the presence of $\mathrm{Na}^{+}$in the incubation medium (Stremmel, 1988; Goré and Hoinard, 1993) and the mineral waters used in this study were highly depleted in $\mathrm{Na}^{+}$(table I). This could in part explain their effect. Nevertheless, the addition of $140 \mathrm{mM} \mathrm{NaCl}$ to these waters did not reestablish the rate of oleate uptake as in control conditions. The decrease in initial rates of oleic-acid uptake $\left(V_{i}\right)$ was correlated with the overall inorganic composition of the water used (table IV). The relationship between the reduction in $V_{i}$ and the ionic composition of the mineral water was highly significant for $\mathrm{Mg}^{2+}, \mathrm{Ca}^{2+}$ and $\mathrm{SO}_{4}{ }^{2-}$ (probably because of $\mathrm{CaSO}_{4}$ and $\mathrm{MgSO}_{4}$ present in the water). On its own, the calcium concentration of these waters (between 0.3 and $11.7 \mathrm{mM}$ ) does not explain the considerable decrease observed in oleate uptake. Even though complexing $\mathrm{Ca}^{2+}$ with EGTA caused a significant increase in oleic-acid uptake (table V), the control values cannot be reached. It thus seems that the action of mineral water on the uptake of oleic acid by intestinal cells can be ascribed to the simultaneous and synergetic presence of several ions (notably $\mathrm{Ca}^{2+}, \mathrm{Mg}^{2+}$ ) (Behling et $a l, 1990$ ) and absence of others (notably $\mathrm{Na}^{+}, \mathrm{Cl}^{-}$).

A study involving the effect of these different ions (in particular $\mathrm{Ca}^{2+}$ and $\mathrm{Mg}^{2+}$ ) on fatty-acid-transport-protein coupling is currently under way by our group and should furnish more precise responses on the mechanism(s) of inhibition reported here.

\section{ACKNOWLEDGMENT}

This study was supported by a grant from BSN group (France). 


\section{REFERENCES}

Appleton GVN, Davies PW, Bristol JB', Williamson RCN (1987) Inhibition of intestinal carcinogenesis by dietary supplementation with calcium. Br J Surg 74, 523-535

Appleton GVN, Owen RW, Williamson RCN (1992) The effect of dietary calcium supplementation on intestinal lipid metabolism. J Steroid Biochem 42, 383-387

Baciulis V, Luthy C, Hofer G, Toplak H, Wiesman UN, Oetliker $\mathrm{OH}$ (1992) Specific and nonspecific stimulation of prostaglandin release by human skin fibroblasts in culture. Are changes of membrane fluidity involved? Prostaglandins 43, 293-304

Behling AR, Kaup SM, Greger JL (1990) Changes in intestinal function of rat initiated with $\mathrm{DMH}$ and fed varying levels of butterflat, calcium, and magnesium. Nutr Cancer 13, 189-199

Bernard A, Fleith M, Carlier H, Hugon JS (1989) Effect of calcium and magnesium ions on the intestinal absorption of oleic acid in vitro. Reprod Nutr Develop $29,63-73$

Buset $M$, Galand $P$, Lipkin $M$, Winawer $S$, Friedman $E$ (1990) Injury induced by fatty acids or bile acid in isolated colonocytes prevented by calcium. Cancer Lett 50, 220-226

Chow SL, Hollander D (1978) Arachidonic acid intestinal absorption: mechanism of transport and influence of luminal factors of absorption in vitro. Lipids 13, 768-773

Chow SL, Hollander D (1979) A dual concentrationdependent absorption mechanism of linoleic acid by rat jejunum in vivo. $J$ Lipid Res 20, 349-356

Goré J, Hoinard C (1987) Evidence for facilitated transport of biotin by hamster enterocytes. I Nutr 117 , 527-532

Goré J, Hoinard C (1989) $\mathrm{Na}^{+} / \mathrm{H}^{+}$exchange in isolated hamster enterocytes: its major role in intracellular $\mathrm{pH}$ regulation. Gastroenterology 97, 882-887

Goré J, Hoinard C (1993) Linolenic acid transport in hamster intestinal cells is carrier-mediated. $J$ Nutr 123, 66-73

Govers MJAP, Van der Meer R (1993) Effects of dietary calcium and phosphate on the intestinal interactions between calcium, phosphate, fatty acids, and bile acids. Gut 34, 365-370

Gu JJ, Hofmann AF, Ton-Nu HT, Schteingart CD, Mysels KJ (1992) Solubility of calcium salts of unconjugated and conjugated natural bile acids. J Lipid Res 33 635-646

Guéguen $L$ (1992) Interactions lipides-calcium alimentaires et biodisponibilité du calcium du fromage. Cah Nutr Diêt 27, 311-315

Hollander D, Chow SL, Dadufaiza VD (1984) Intestinal absorption of free oleic acid in the unanesthetized rat: evidence for a saturable component? Can J Physiol Pharmacol62, 1136-1140
Jacobson K, Papahadjopoulos D (1975) Phase transitions and phase separations in phospholipid membranes induced by changes in temperature, $\mathrm{pH}$, and concentration of bivalent cations. Biochemistry 14 , 152-161

Jandacek RJ (1991) The solubilization of calcium soaps by fatty acids. Lipids $26,250-253$

Lipkin M, Newmark MS (1985) Effect of added calcium on colonic epithelial cell proliferation in subjects at high risk for familial colonic cancer. $N$ Engl J Med $313,1381-1384$

Lowry OH, Rosebrough NJ, Farr AL, Randall RJ (1951) Protein measurement with the Folin phenol reagent. J Biol Chem 193, 265-275

Mattson FH, Nolen GA, Webb MR (1979) The absorbability by rats of various triglycerides of stearic and oleic acid and the effect of dietary calcium and magnesium. J Nutr 109, 1682-1687

Molina MT, Ruiz-Gutierrez V, Vasquez CM, Bolufer J (1990) Changes in uptake of linoleic acid and cholesterol by jejunal sacs of rats in vitro, after distal smaltbowel resection. Scand J Gastroenterol 25, 613-621

Newmark HL, Wargovich MJ, Bruce WR (1984) Colon cancer and dietary fat, phosphate and calcium: a hypothesis. J Nat/ Cancer Inst 72, 1323-1325

Potter BJ, Sorrentino D, Berk PD (1989) Mechanisms of cellular uptake of free fatty acids. Annu Rev Nutr $9,253-270$

Sallee VL (1974) Apparent monomer activity of saturated fatty acids in micellar bile salt solutions measured by a polyethylene partitioning system. J Lipid Res 15, 56-64

Saunders DR, Sillery J (1979) Effect of calcium on absorption of fatty acid by rat jejunum in vitro. Lipids 14, 703-706

Sorenson AW, Slattery ML, Ford MH (1988) Calcium and colon cancer: a review. Nutr Cancer 11, 135145

Strauss EW (1977) Effects of calcium and magnesium ions upon fat absorption by sacs of everted hamster intestine. Gastroenterology 73, 421-424

Stremmel W (1988) Uptake of fatty acids by jejunal mucosal cells is mediated by a fatty-acid binding membrane protein. J Clin Invest 82, 2001-2010

Stremmel W, Lotz G, Strohmeyer G, Berk PD (1985) Identification, isolation and partial characterization of a fatty acid-binding protein from rat jejunal microvillus membranes. J Clin Invest 75, 1068-1076

Trotter PJ, Storch J (1991) Fatty acid uptake and metabolism in a human intestinal cell line (Caco-2): comparison of apical and basolateral incubation. $J$ Lipid Res 32, 293-304

Van der Meer R, Welberg JWM, Kuipers F et al (1990) Effects of supplemental dietary calcium on the intestinal association of calcium, phosphate, and bile acids. Gastroenterology 99, 1653-1659 
Wargovich MJ, Eng VWS, Newmark HL, Bruce WR (1983) Calcium ameliorates the toxic effect of deoxycholic acid on colonic epithelium. Carcinogenesis 4 , 1205- 1207

Wargovich MJ, Eng VWS, Newmark HL (1984) Calcium inhibits the damaging and compensatory proliferative effects of fatty acids on mouse colon epithelium. Cancer Lett 23, 253-284

Weisburger JH (1991) Causes, relevant mechanisms, and prevention of large bowel cancer. Semin Oncol $18,316-336$
Westergaard H, Dietschy JM (1976) The mechanism whereby bile acid micelles increase the rate of fatty acid and cholesterol uptake into the intestinal mucosal cell. J Clin Invest 58, 97-108

Willett WC (1989) The search of the causes of breast and colon cancer. Nature (Lond) 338, 389-394

Willett WC, Stampfer MJ, Colditz GA, Rosner BA, Speizer FE (1990) Relation of meat, fat, and fiber intake to the risk of colon cancer in a prospective study among women. N Engl J Med 323, 16641672 